\title{
Fiscal Policies as a Main Pillar of Macroeconomic Policies and Their Impact on Economic Development. Study Model - Tax Administration of Kosovo (TAK)
}

\author{
Mr.Sc.Armend Aliu \\ PhD Candidate - European University of Tirana \\ Lecturer at University of Pristina, Faculty of Economics \\ Ulpiana, E30, Nr.19 - 10000 Pristina, Kosovo \\ Tel: +377 (0) 44511 411, Email: armend.aliu@uni-pr.edu ; armend_aliu@hotmail.com
}

Aulent Guri

PhD Candidate - European University of Tirana

Environmental Expert at G\&G Group

Tirana, Albania.Email: aulentguri@gmail.com

Donjeta Abazi

Master in progress in Banking and Finance- University of Pristina, Faculty of Economics Administrative Assistant at Menargon Accountings Ulpiana - 10000 Pristina, Kosovo

Jasmina Lumani

PhD Candidate - European University of Tirana Lecturer at Luigj Gurakuqi University, Faculty of Economy Shkodra, Albania. Email:j_lumani@yahoo.com

\section{Doi:10.5901/mjss.2013.v4n10p137}

\section{Abstract}

In economic development of every country, incomes from different taxes play a major role. So, fiscal policies shows that they can support economic development a lot, even in transitions countries. However, the slowdown in economic growth in most countries of the region as well as in the euro area has influenced the economy of Kosovo to slow the pace of growth compared with the previous year. External sector is regarded as the most influential factor in slowing economic growth as a result of the decline in exports, the marked fall of foreign direct investment as well as easy to fall recorded deliveries from immigrants. Experience from past financial crises, suggests that lasting recovery requires a review of the policies and procedures of fiscal policy, also our country in general need to come out with a clear view of what kind of coordination device they want to "invent" in order to increase incomes from different taxes and in particular to find priorities in order to invest on those sectors. On this paper we will focus on the impact that good fiscal policies have on promoting economic development and also on sustainable budget.

Keywords: Fiscal Policy, macroeconomic policies, economic development, Tax Administration of Kosovo, taxes, etc.

\section{Abbreviations and Acronyms}

- CEFTA

- $\mathrm{CB}$

- EU

- FE

- FP

- GDP
Central European Free Trade Agreement

Commercial Banks

European Union

Fiscal Equipment

Fiscal Policy

Gross Domestic product 


\begin{tabular}{|c|c|}
\hline $\begin{array}{ll}\text { - } & \text { GOVT } \\
\text { - } & \text { IMF } \\
\text { - } & \text { KPST } \\
\text { - } & \text { RKE } \\
\text { - } & \text { TAK } \\
\text { - } & \text { VAT } \\
\text { - } & \text { WB }\end{array}$ & $\begin{array}{l}\text { Government } \\
\text { International Monetary Fund } \\
\text { Kosovo Pension Savings Trust } \\
\text { Ministry of Finance and Economy } \\
\text { Republic of Kosovo } \\
\text { Tax Administration of Kosovo } \\
\text { Value Added Tax } \\
\text { World Bank }\end{array}$ \\
\hline
\end{tabular}

\section{Introduction}

Macroeconomic is a part of economic science that studies global economic phenomenon, aggregation of individual behavior, on international or national level or a sector of the economy.

It seeks to explain the relationship between various macroeconomic indicators, such as gross national income, balance of payments, growth, investments, consumption, unemployment rate, inflation, etc. Macroeconomic was developed based on the concepts elaborated by J.M.Keynes (1883-1946) through his book "General Theory of Employment, Interest and Currency"

Relying on a complex modeling and very well elaborated, today a lot of states, international institutions and private organization are using macroeconomic so much, to predict evolution of different variables in function of transformations of economic and political environment. On the contrary, microeconomics focuses on the factors that influence decisions of economic agents in individual level (businesses, household).

Macroeconomics is the theoretical approach that studies economy through relations that exist between major economic aggregates, such as incomes, investments, consumption, unemployment rate, inflation, and as it is, it constitutes the main tool of economic policies analysis of the states or international organizations.

So considering the relationship between the major economic aggregates, macroeconomics seeks to explain these reports and predicts their evolutions against changes of conditions, as in case of a shock (i.e. increasing of oil price) or implementation of new economic policy. Contrary to microeconomics, that justifies the partial equilibrium, macroeconomics always justifies the general equilibrium of economy.

Macroeconomists thought that there could never be a great depression before 1930 and they were convinced that a market-driven economy was stable and the Government intervention was unnecessary (Adam Smith 1723 - 1790).

But a market-driven economy is inherently unstable ${ }^{1}$ and on this view the inherent instability of the marketplace required Government intervention.

\section{Macroeconomic Policy Objectives}

Generally, the objectives of macroeconomic policies are to maximize the amount of national income, providing economic growth to increase the benefits and standards of living of businesses and individuals in the economy. There are also many secondary objectives which are held to lead to the maximization of income over the long run. While there are variations between the objectives of different national and international entities, must follow the ones detailed below:

1. Sustainability - that means the rate of growth which allows an increase in living standards without excessive structural and environmental difficulties.

2. Full employment - means that everyone from those who are able and have a good will to have a job can get one, given that there will be a certain amount of frictional, seasonal and structural unemployment (referred to as the natural rate of unemployment).

3. Price stability - this mean that when prices remains stable, and there is not a rapid inflation or deflation. Price stability is not necessarily the same as zero inflation, but instead steady levels of low-moderate inflation is often regarded as ideal. It is worth noting that prices of some goods and services often fall as a result of productivity improvements during periods of inflation. However, inflation is a good measure of 'price stability'. Zero inflation is often undesirable in an economy. ("Internal Balance" is used to describe a level of economic activity that results in full employment without inflation.)

\footnotetext{
1 John Maynard Keynes 1885 - 1942 developed an alternate view of the macro economy through which means the intervention of Government on the economy.
} 
4. Payment Balance/External Balance - means the equilibrium in the balance of payments without the use of artificial constraints. That is, exports roughly equal to imports over the long run.

5. Equitable distribution of income and wealth - a fair share of the national incomes, more equitable than would be in the case of an entirely free market.

6. Increasing Productivity - more output per unit of labor per hour. Also, it could also be described as output per unit of factor inputs per hour.

\section{The Role Of State In The Economy}

On each modern economy the state has it's undisputed role into the economic activity and sometimes those repeated crisis won't pass without state intervention!

There are different important factors that justifying the participation of the state on economic activity, like:

- Very often market shows no perfection on functioning itself and that brings in a situation that it can not pass out without intervention of the state. Economic crisis dictate clearly the necessary of the state intervention.

- The state also undertakes offering for all citizens with goods and services, which are: education, medicine services, water supply, infrastructure, that private sector can't offer alone.

- The state intervenes on the market to ensure stable economic growth, price stability and increasing employment. State effects on the way of private sector functioning, through: a) establishment of market regulatory system in order to protect consumers, workers, environment behaviour and also avoids uncompetitive practices, b) taxes, credit system that apply to businesses and hauseholds, c) giving the rights of use and development of different national wealth.

From the points above, the role of the states on economic development depends on how those states are able to make good policies and policies through which all possible sectors will functions and also the state itself will function.

So, it is worthy to emphasize that if good macroeconomic policies were created, those will lead to efficient functioning of economy and from this view we can say that basic tasks of each state in relation to the economy is creation of good policies in order to have an effective and prosperity of the economy.

In function of stable economic growth followed by decrease of unemployment, balance of payments, keeping of inflation in normal rates, increasing of investments, are different kind of policies, like: fiscal policies, monetary policies, income policies, policy of foreign economic relations, but on this paper I will focus more on fiscal policies as a main part of macroeconomic policies on economic development and also on elaborating of Tax Administration of Kosovo, which is as a main institution that administer taxes and support Ministry of Finance on realizing of it's objectives

\section{Fiscal Policy}

Fiscal policy is one of the macroeconomic policies, that is considered with high importance and that plays a major role in economic development and we can hear very often that fiscal policy is an integral part of modern economic policy.

Fiscal policies includes the concerns in use of Government revenue collection (taxation) and spendings to influence the economic activity².

There are two important instruments of FP: changes in Government expenditures (spendings) and also of the taxation system in different sectors and these changes absolutely may have affect/impact on macroeconomic variables, like: Aggregate Demand, distribution of incomes, resource allocation model within Govt. sector, but also in long term period it might affect aggregate supply.

Depends on economic situations, there are different kind of fiscal policies attitude:

$>$ When an economy is in equilibrium, usually the state undertakes Neutral Fiscal Policy, that means the total Govt. Spendings are covered from taxes revenue and in general the budget outcome has neutral effect on economic activity.

$>$ When Govt. Spendings exceeds tax revenues then state apply Expansionary Fiscal Policy and usually it is undertaken when the economy is in recession and of course on that case the state will face off with budget deficit,

\footnotetext{
${ }^{2}$ Library of Economics and Liberty website: http://www.econlib.org/library/Enc/FiscalPolicy.html
} 
When the Govt. Spendings are lower than tax revenues the state apply Contractionary Fiscal Policy and usually it is undertaken when the state want to pay the Government debt and in cases when the Govt. debt are in high level.

Depends on business cycle, Govt should also react through certain active policies. When an economy suffers from recession and when recovery is delayed for a long time and also unemployment is high, the Govt should deficit spendings and during the expansion or the economic prosperity times the suppression of inflation, should push the Govt to react through increasing taxes or cutting their expenditures. Such kind of policies that acted against the flow of business cycle, is called Countercyclical Fiscal Policies ${ }^{3}$.

Below, through diagrams are presented the reaction of FP in the short run based on Keynes model.

Diagram 1. Keynesian Fiscal Policy in the Short Run ${ }^{4}$

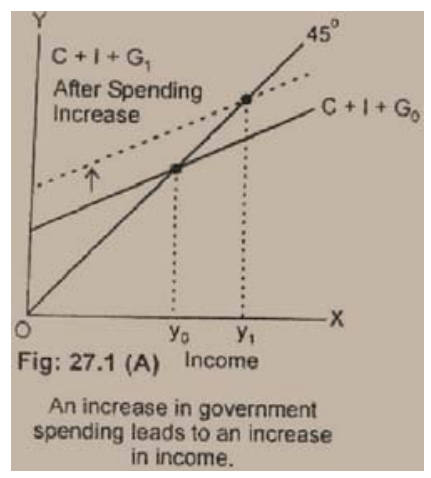

Fig. A. An increase in Government increase in income.

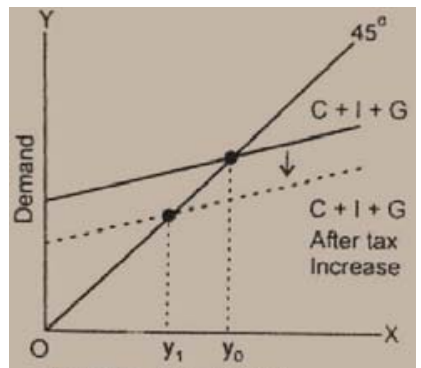

Fig: 27.1 (B) Income

An increase in taxes leads

to a decrease in income.

Fig. B. An increase in taxes leads to spending leads to an a decrease in income.

Taxes and spendings are both parts of Fiscal Policy, that the Govt. needs to use for reactions:

- Taxes called every payment which are obligatory by law and which are made from either businesses and private individuals in favor of the state. These payments should be done based on their incomes, wealth and also on goods and services that they benefit. So each person is obliged by law to pay taxes and other contributions ${ }^{5}$.

Normally taxes are $90 \%$ of all the state revenue, but unfortunately in Kosovo this relation doesn't exist. The Kosovo Budget, still is filled mainly from custom revenues and incomes from taxes become after.

\footnotetext{
${ }^{3}$ Keynes, John Maynard (1924) -"The Theory of Money and the Foreign Exchanges", A Tract on Monetary Reform.

$4 \mathrm{http}: / /$ www.economicsconcepts.com/What_is_fiscal_policy.htm

${ }^{5}$ Constitution of the Republic of Kosovo, Article 119
} 
- Spendings or expenditures are all Govt. investments and consumption but there aren't included transfer payments, made by the state.

\subsection{Tax administration of Kosovo}

TAK was established on 17 of January 2000 under the responsibilities and administration of UNMIK and also with foreign general director. Gradually the competences and responsibility has been transferred to the domestics and on 18 of February 2003 TAK all the responsibilities was transferred to the MFE and from that time TAK had a domestic general director.

Tax Administration of Kosovo is the only Authority, under the responsibility of Ministry of Finance and Economy that administres taxes, brings general administrative rules that are obliged to be implemented by either, TAK and Taxpayer.

MFE will have exclusive role in creating of income model and fiscal policy for the state and TAK will continue to support MFE on doing of those job, but administration of taxes on operational view/perspective will be the exclusive responsibility of TAK and out of MFE control, with certain exceptions which are:

$>$ Involvement in the appointment of the General Director of ATK, and

$>$ Approval and publication of the interest rates for arrears of payments and delayed refunds.

TAK will be responsible for implementing of law over the taxes which are applicable in Kosovo, like:

- Person Income Tax,

- Corporate Income Tax,

- Value Added Tax,

- Profit tax,

- Presumptive tax,

- Payments for pensional contributions which administres KSPT, and

- Also for all others taxes and contributions that MFE requires.

\subsubsection{Mission of TAK is:}

$>$ Increasing in maximum the voluntary compliance, which means declaration and payment of tax liability by the taxpayer, observing the law provision related to the amount of tax payable and respect the deadline of payment of that amount, without intervention of TAK.

$>$ Offering professional, transparent and effective services towards the taxpayer community, making clear for their liabilities about tax payments.

$>$ To ensure and enforcement the implementation of tax laws in order to collect the revenues for Kosovo Budget in an efficient way and reducing costs.

\subsubsection{Values and vision of TAK are6:}

$>$ Integrity and sincerity is the basic issue of TAK, that ensure equal treatments towards taxpayers and right implementations of laws,

$>$ Professionality is the success key of mission fulfillment, aiming to continuous improvements toward higher standards.

$>$ Transparence will be important in order to build strong relationship of trust between TAK and taxpayers.

$>$ Respect towards taxpayers is showed through the contacts between two parts, when the TAK accept the rights of taxpayers and TAK liabilities.

$>$ Flexibility means the basic issues for new developments in TAK.

State in the implementation of tax policy should be based on certain principles through which should achieve it's goals:

- Financial and political principles: here are included principles of adequacy and suitability.

- Economic and political principles: that has to do with choosing the source of taxes and tax types,

\footnotetext{
${ }^{6}$ http://www.atk-ks.org/per-ne/?lang=en
} 
- Social and political principles: that involves meaning that taxes should be generalised and equal for all taxpayers without any distinguish.

- Technical/Administrative principles: that means determination of taxes then suitability of tax payments and collection of taxes with less expenses.

\section{Macroeconomic View}

Macroeconomic view means and shows all the indicators of the entire economy.

As it is described in other countries, also MFE describes different sectors divided, as a part of macroeconomic view, like below:

\subsection{Real Sector}

Where is stated the growth of economy, expressed from the annual growth of GDP and also the Consumer Price Index. From the statistics derived from MFE, it is estimated that domestic economy has a rate of growth during 2012 from $2.4 \%$, on contrary with the year 2011 that the economic growth was 4.5\%, while MFE has the first prediction for a growth of $3.7 \%$ for the year 2013 , where the main participant on that growth will be increasing of general consumption, that will contribute with a scale of $2.3 \%$. After that, private investment will contribute with the scale of approximately $1 \%$ and public investments with $0.8 \%$. Meanwhile the main concern is that exports won't be the main contributors on that growth, the rate of which is expected to be $0.6 \%$, while imports expected to have a negative impact on economic growth with approximately the scale of $1 \% \%^{7}$.

Meantime, during this quarter (2013) general prices measured by CPI recorded an increase, approximately $2.9 \%$ and based on the supplementary data that MFE has, it is expected that prices for the year 2013 will be an increase from $1.7 \%$ compared with the year 2012.

\subsection{External Sector}

When we are talking about the external sector, however we do not enjoy the fact that should mention the data or figures about this.

Because Kosovo have a huge difference between imports and exports and the trade balance is not in equilibrium, because of the high level of imports, these conditions leads to an unstable situation and also it is a crucial issue on dependence of our state to those with which we do business.

Because of the high level of imports of all kind of products, it is understood that Kosovo doesn't control the changes on prices.

Also the slowing of growth on EU countries continues due to the congestion into the foreign environments (downward fluctuations in the demand for export), and the effects of tight fiscal policies undertaken by states which are facing with budget deficits.

Evolutions in EU, influenced also economic situation in Kosovo. The downwards trend in exports has affected the trade balance to continue being deteriorated in line with continuing on increasing of imports, which on the first semester of 2012 recorded growth in order to respond to the demand of domestic consumption.

Imports continue the growth trend, that on first semester of 2012 recorded nominal value from 1.122 bil. Euro, with a growth from $3 \%$ compared to previous year 2011, and that increased the trade deficit on amount of 988 mil. Euro from the 928 mil. Euro as it was. $41 \% 8$.

Exports on other hand, have a low contribution to GDP and during the period of 2009-2014 increased on average

The destination places of exports were mainly EU countries (Italy 70\%, following with Germany, etc.) and places which are members of CEFTA9.

\footnotetext{
7 http://esk.rks-Govt.net/ENG/publikimet/cat_view/13-national-account

8 http://esk.rks-Govt.net/ENG/publikimet/cat_view/14-external-trade/90-external-trade-statistics-2013

${ }^{9}$ The Central European Free Trade Agreement (CEFTA) is a trade agreement between non-EU countries in Central and South-Eastern Europe.
} 


\subsection{Financial Sector}

Financial sector of Kosovo continue to maintain stable, sustainable and profitable.

Gross loans continue to be the main way of financing to the economy, which recorded growth from $9 \%$ on first semester of the year 2012, from 1.624 bil. Euro, on first half of 2011 to 1.776 bil. Euro on first half of 2012.

Also deposits recorded growth but with slow rhythm as well as loans, and in first semester of 2012 the growth was from 8\%, which means from 1.957 bil. Euro (first sem. 2011) to 2.108 bil. Euro (first sem. 2012) ${ }^{10}$.

\subsection{Fiscal Sector}

Above we sow different data for the different sectors as a part of macroeconomic view.

On this paper the focus of studying is fiscal policies as a special part of macroeconomic policies, and when the word is to Kosovo fiscal policy I should stress more the fact that the fiscal policy is the only instrument/tool through which Kosovo Government use to ensure macroeconomic stability and here also should be mentioned that CBK doesn't have the right to issue/print money, and because of that it can't also use monetary policy for intervention on economy and on this point it is so important to have a special attention about fiscal policy and using of it and in the same time it is one of the important priorities for policy makers.

As I mention above, MFE has the right to establish state policies and TAK is the only authorized institution under the responsibilities of the MFE that administres taxes.

Considering that the only instrument of economic policies in Kosovo is fiscal policy, on this case MFE tendencies always was on creating a simple tax system with aims of expanding types of taxes, which will support the private sector.

Also the biggest challenge of Kosovo Govt. supposed to be the fact that the main participant on budget revenues are taxes from borders or as it is called "custom incomes".

So, in the end of 2012 incomes from taxes recorded the amount of 283.9 mil. Euro, which means it was a growth from $9 \%$ (or 22.8 mil. Euro) compared with the previous year. While the amount of pension contributions for 2012 was 113.1 mil. Euro.

Whereas, the participation of different types of taxes in total incomes wasn't in the same amounts. Main contribution to the total incomes has given VAT (with 45.78\%), followed by Tax on Corporate Income (22.08\%), and after were Tax Withheld (21.17\%), Tax on Individual Businesses (9.13\%), withholdings tax on interest, ownership rights, rent, winnings in the lottery and games of chance and of the non-resident (0.57\%), Presumptive Tax (0.14\%), Tax on Profit $(0.04 \%)$, other taxes $(1.09 \%)$.

Tab. 1. Incomes collected by type of taxes

\begin{tabular}{|c|c|c|c|c|c|c|c|}
\hline \multirow{2}{*}{ Tax type } & \multicolumn{3}{|c|}{ Incomes per year } & \multirow{2}{*}{$\%$} & \multirow{2}{*}{ Projection 2012} & \multirow{2}{*}{\multicolumn{2}{|c|}{$\begin{array}{l}\text { Comparing } \\
2012 / 2011\end{array}$}} \\
\hline & 2010 & 2011 & 2012 & & & & \\
\hline 1 & 2 & 3 & 4 & $5=4 /$ total & 6 & $7=4 / 6$ & $8=4 / 3$ \\
\hline Presumptive tax & $283,649.00$ & $868,983.00$ & $405,364.00$ & $0.14 \%$ & $629,154.00$ & $64.00 \%$ & $47.00 \%$ \\
\hline Tax on profit & $582,999.00$ & $1,792,756.00$ & $116,197.00$ & $0.04 \%$ & $662,050.00$ & $18.00 \%$ & $6.00 \%$ \\
\hline Vat & $95,007,780.00$ & $121,437,993.00$ & $129,960,077.00$ & $45.78 \%$ & $131,000,000.00$ & $99.00 \%$ & $107.00 \%$ \\
\hline $\begin{array}{l}\text { Tax on wages } \\
\text { withholding }\end{array}$ & $44,208,930.00$ & $55,668,304.00$ & $60,089,290.00$ & $21.17 \%$ & $48,000,000.00$ & $125.00 \%$ & $108.00 \%$ \\
\hline $\begin{array}{l}\text { Tax on individual } \\
\text { businesses }\end{array}$ & $25,466,740.00$ & $23,517,097.00$ & $25,916,434.00$ & $9.13 \%$ & $36,000,000.00$ & $72.00 \%$ & $110.00 \%$ \\
\hline $\begin{array}{l}\text { Tax withheld on } \\
\text { interest, rent... }\end{array}$ & $2,932,560.00$ & $1,375,507.00$ & $1,630,724.00$ & $0.57 \%$ & $3,500,000.00$ & $47.00 \%$ & $119.00 \%$ \\
\hline $\begin{array}{l}\text { Tax on corporate } \\
\text { income }\end{array}$ & $51,945,800$ & $54,564,163$ & $62,680,757$ & $22.08 \%$ & $68,008,796.00$ & $92.00 \%$ & $115.00 \%$ \\
\hline Other taxes & 732,795 & $1,898,361$ & $3,100,088$ & $1.09 \%$ & 0.00 & $0.00 \%$ & $163.00 \%$ \\
\hline Total & $221,161,253.00$ & $261,123,164.00$ & $283,898,932.00$ & $100.00 \%$ & $287,800,000.00$ & $99.00 \%$ & $109.00 \%$ \\
\hline
\end{tabular}

Source: Tax Administration of Kosovo: Annual Working Report - 2012

${ }^{10}$ http://www.bqk-kos.org/?cid=2,134 
Diagram 1. Graphic review by type of taxes

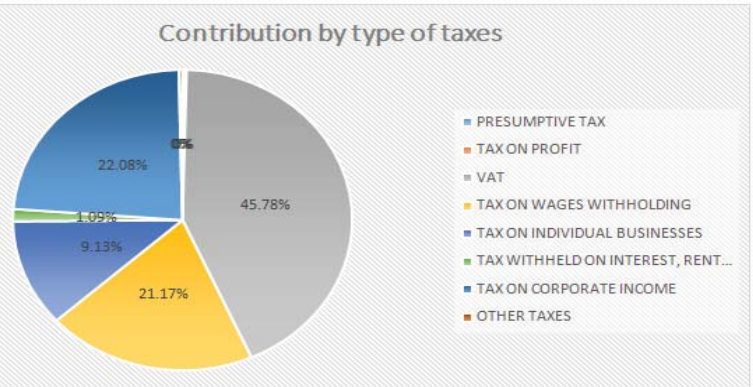

Source: Tax Administration of Kosovo: Annual Working Report - 2012

As it is mentioned above VAT is the main contributor to the total incomes with $43 \%$.

Because of the sensitivity of fiscal policy, there have been few intervention by the RKS Govt. in changing of tax rates.

During the year 2012 MFE seeks for the possibilities of FP review, in order to offer more favorable environment for businesses and citizens of RKS in general, so MFE proposed amendment of law no. 03-L-146 for:

$>$ VAT: i.e. exempt from VAT paying of hospital care, medical care, private universities, electronic and print media,

$>$ Excise tax rate: for more contribution towards protecting the environment, improving traffic safety and increased efficiency in the use of electricity, MFE has proposed that the excise rate applied in bag (3:00 euro per $\mathrm{kg}$ ), roasted simple electricity ( 0.3 eur per piece) and old tires (5:00 euro per piece).,

$>$ tax on personal income: In order to encourage small enterprises to shift from presumptive tax at the standard tax system, MFE increased tax rate from $5 \%$ to $9 \%$ for business activities with annual gross income up to fifty thousand $(50,000$ euro) which engages the professional activities, services, crafts, entertainment, etc.

$>$ custom tax: Through this tends to create a more favorable environment for business development, providing customs exemptions on goods used as raw material,

$>$ Semi products, packaging, machinery which serve for production including here also production lines.

$>$ Also have been other changes in administrative part, as: creating facilities and supporting businesses through simplified procedures in TAK and Custom, that from nine documents that was required for clearance of goods now require only four documents. MFE in order to protect environment put an ecological tax on vehicles and for the vehicles weighed until 3.5t. it cost 10 euro and for those over 3.5t. it cost 30 euro.

Except these changes, RKS also signed agreement with Turkey for avoiding of double taxation and prevention of fiscal evasion, and also signed different other agreement with Macedonia, Albania, Germany, UK, Holland, Austria, France, Belgium.

Through these changes on FP, the Govt. of RKS expects to have a reduction in local production costs, stimulation of private investment both domestic and foreign, as well as to increase competitiveness between them.

Also there has been increasing in performance of TAK in fulfilling the tasks, because of the changes and due to raising awareness of the taxpayers.

- Collection of debts through enforced collection has been increased on 2012 to 37 mil. Euro from the 32.05 mil. Euro as it realized on 2011, expressed on \% it was a growth from $15.4 \%$.

- Refunds ${ }^{11}$ and returns are reviewed for 3288 taxpayers, and were approved 32.7 mil. Euro, and compared the reviewing of refunds with annual predicted projection from 32.5 mil. Euro, approved refunds have been realized in amount of 32.7 mil. Euro or $0.6 \%$ more.

- Fiscalization process doesn't went so good. Until now 16885 businesses are fiscalized with a number of 20784 fiscal equipments, and 10714 fines are issued by the tax inspectors, which doesn't has any impact to the businesses to get equipped with $\mathrm{FE}$.

${ }^{11}$ Refund is the return of funds that TAK pays in the name of businesses with the request of businesses when they have done payments before (like VAT, etc.). 


\section{Conclusions}

This paper describes the contribution that macroeconomic policy can give to promote a rebalancing of growth and in particular the contribution of fiscal policies on economic development. As it is mentioned above Kosovo doesn't find still a solution to make changes in macroeconomic policies in order to increase the incomes from taxes and decrease the those from custom (which are the main incomes of the state).

So, a comprehensive review of the objectives and instruments of macroeconomic policy is needed and in particular of fiscal policies, in order to learn from past experience and reform the policy in a constructive way.

First of all, fiscal policies should be in harmonize with the level of development of the country, it means if the country is in developing stage (like our country) fiscal policies should not be so contractionary but it should be expansive, and also it should be selective depends on the sector with more power to influence the economy.

From these view the main points as conclusions are as below:

$>$ A clearer policy for rural areas is required. Rural areas pose a particular challenge for Kosovo. In one hand it is necessary for increasing the production of goods and on other hand it is also crucial to substitute the domestic product that will be produced with those from imports and that will be the only way for reducing of imports and to put in equilibrium the balance trade, which actualy is in a great disproportion. The Govt can use the fiscal policy by cutting taxes for agricultural machinery, raw materials, over sales of agricultural products, followed by subsidies for farmers in order to encourage agricultural production, doing of direct payments for farmers, protect the prices of agricultural products through increasing the custom taxes for imports.

$>$ The key focus of tax policy reforms is to be growth-friendly, while addressing not only short-term but also longer-term challenges (such as using of working capital that Kosovo has, etc.) to sustainable public finances.

$>$ Even that a consider number of businesses actually bought fiscal equipment's, it is crucial to continue with faster rhythm equipping also the rest of businesses, because only a business with FE ensure evidence of all transactions and reducing fiscal evasion.

$>$ Also Kosovo Govt can do a lot on improvement of investment environment: In addition, there is significant potential to invest in improving the investment climate to encourage private investment and foreign investments. Although some measures to improve climate do not necessarily require significant expenditure, e.g., improvements in Governance, investor protection, legal rights, taxation and regulation, including improving infrastructure, investment in education and training to raise skill levels, enforcement of legal protections.

\section{References}

ADBI Institute, Asian developed bank institute, No.266 (February 2011), Peter J Morgan -

Albanian Bank, Law Department - Studim juridik mbi mundësitë e adoptimit të rregullave fiskale në Shqipëri.

Asian Development Bank Institute, (5 October 2011-Tokyo), Suren Adamyan (State Revenue Committee of Armenia) - Key tax reforms in Armenia.

Commonwealth - Trade hot topics, Issue 68, (January 2010). Samantha Attridge and Euan MacMillan - Sustaining Recovery: The Role of Macroeconomic Policy and Trade.

Department of Economic and Public Policies, No.11 (December 2011-Pristina) - Macroeconomic Buletin Januar-June, 2012.

http://www.imf.org/external/index.htm

http://www.mti-ks.org/en-us/Ministry-of-Trade-and-Industry

http://www.worldbank.org/

Kosovo Agency of Statistics, 3rd Series, (December 2012-Pristina) - Gross Domestic Product by economic activities (2006-2011).

Ministry of Finance and Economy, (February 2013) - Budget report for February 2013.

Ministry of Finance and Economy, Macroeconomic Unit, No.12, (2013) - Macroeconomic View for January-March 2013.

Minnesota Center for Fiscal Excellence (Sound tax policy, efficient spending, accountable government). Taxing decision matter: A guide to good tax policy.

OECD, July 2010 - United Kingdom Policies for a Sustainable Recovery.

Organization for economic co-operation and development, Asian Development Bank Institute, Tokyo, (4 October 2011), David Partington (OECD Secretariat) - An introduction to the role and structure of tax treaties.

Prof.Dr.Gazmend Luboteni (2007-Pristina) - Financat e Korporatave.

Prof.Dr.Sabahudin Komoni (2008-Pristina) - Financat Publike (University of Pristina - Faculty of Economics)

Tax Administration of Kosovo, (2013-Pristina) - Annual working report 2012.

Tax Administration of Kosovo, 2nd Edition, (November 2011-Pristina) - Kosovo Tax Legislation.

The Role of Macroeconomic Policy in Rebalancing Growth (ABDI working paper series). 